\title{
Hubungan ear lobe crease dengan penyakit jantung koroner
}

\author{
${ }^{1}$ Jacqueline A. Fuzairi \\ ${ }^{2}$ Dewi U. Djafar \\ ${ }^{2}$ Agnes L. Panda \\ ${ }^{1}$ Kandidat Skripsi Fakultas Kedokteran Universitas Sam Ratulangi Manado \\ ${ }^{2}$ Bagian Kardiologi dan Kedokteran Vaskular Fakultas Kedokteran \\ Universitas Sam Ratulangi Manado \\ Email: JFuzairi.12035@yahoo.com
}

\begin{abstract}
Cardiovascular disease is a huge burden in terms of mortality, disability, and morbidity in this day. Prevention of cardiovascular disease is based on the physical signs. Waist circumference, Ankle Brachial Index (ABI) and Carotid Intima Media Thickness (CIMT) are useful to recognize occult atherosclerosis, so as ear lobe crease. However, medics have less attention about examination of ear lobe crease for detection of coronary artery disease. This study aimed to determine the relation of ear lobe crease and coronary artery disease. This was an analytical observational study with a case control design. The results showed that there were 45 samples for control group and 45 samples for case group. The statistical analysis showed the $X^{2}=21.78$ with a p value $<0,001$ which indicated that there was a significant correlation between Ear Lobe Crease and Coronary Artery Disease. The OR = 8.9\% (95\% CI $3.4-23.3$ ) meant that if a person had ear lobe crease, the possibility of coronary artery disease was 8.9 times higher than a person without ELC. Conclusion: There was a significant correlation between Ear Lobe Crease and Coronary Artery Disease.
\end{abstract}

Keywords: ear lobe crease, coronary artery disease

\begin{abstract}
Abstrak: Penyakit Kardiovaskular merupakan penyebab utama kematian, kecacatan dan kesakitan saat ini. Deteksi penyakit kardiovaskular sebagai tindakan pencegahan dapat dilihat melalui pemeriksaan fisik. Pengukuran lingkar pinggang, Ankle Brachial Index (ABI), dan Carotid Intima Media Thickness (CIMT) sangat berguna untuk penanda aterosklerosis subklinis, begitu pula dengan Ear Lobe Crease. Namun sampai saat ini, pemeriksaan Ear Lobe Crease untuk menilai penyakit jantung koroner kurang mendapat perhatian petugas medis. Tujuan penelitian ini adalah untuk mengetahui apakah terdapat hubungan antara Ear Lobe Crease (ELC) dengan Penyakit Jantung Koroner. Metode: Penelitian ini dilakukan menggunakan metode penelitian analitik observasional dengan case control. Hasil penelitian: Sampel penelitian terdiri dari 45 orang untuk kelompok kontrol dan 45 orang untuk kelompok kasus. Berdasarkan uji $\mathrm{X}^{2}$ diperoleh $\mathrm{X}^{2}=21,78$ dengan $\mathrm{p}<0,001$. Hasil ini menunjukkan bahwa adanya hubungan yang sangat bermakna antara Ear Lobe Crease (ELC) dengan Penyakit Jantung Koroner ( $\mathrm{p}<0,001)$. Dalam uji ini, juga diperoleh OR = 8,9 (95\% CI: 3,4 23,3). Odd Ratio (OR) ini menyatakan bahwa bila seseorang ditemukan adanya ELC, maka orang tersebut berisiko 8,9 kali mendapat Penyakit Jantung Koroner dibanding dengan orang tanpa ELC. Simpulan: Terdapat hubungan yang sangat bermakna antara Ear Lobe Crease (ELC) dengan Penyakit Jantung Koroner.
\end{abstract}

Kata kunci: ear lobe crease, penyakit jantung koroner.

Penyakit Kardiovaskular merupakan penyebab utama kematian, kecacatan dan kesakitan saat ini. Sekitar 17,3 juta penduduk dunia meninggal akibat penyakit 
kardiovaskular pada tahun 2008 (mewakili $30 \%$ kematian di dunia), terdiri dari 7,3 juta akibat penyakit jantung koroner dan 6,2 juta akibat stroke. Dan diperkirakan, 23,6 juta penduduk dunia akan meninggal akibat penyakit kardiovaskular pada tahun $2030 .{ }^{1}$

Menurut Riskesdas 2013, prevalensi jantung koroner berdasarkan wawancara terdiagnosis dokter di Indonesia sebesar 0,5 persen, dan berdasarkan terdiagnosis dokter atau gejala sebesar 1,5 persen. Prevalensi jantung koroner berdasarkan terdiagnosis dokter tertinggi Sulawesi Tengah (0,8\%) diikuti Sulawesi Utara, DKI Jakarta, Aceh masing-masing 0,7 persen. Sementara prevalensi jantung koroner menurut diagnosis atau gejala tertinggi di Nusa Tenggara Timur (4,4\%), diikuti Sulawesi Tengah (3,8\%), Sulawesi Selatan (2,9\%), dan Sulawesi Barat (2,6\%). ${ }^{2}$

Berdasarkan penelitian yang dilakukan di RSUP Prof. R. D. Kandou Manado periode Januari sampai Desember 2010, didapatkan dari 230 kasus, sebanyak 136 kasus (59,13\%) tidak disertai dengan penyakit penyerta atau catatan tidak lengkap dan 94 kasus (40,87\%) penyakit jantung koroner disertai dengan penyakit penyerta. ${ }^{3}$

Penyakit jantung koroner disebabkan karena sumbatan plak ateroma pada arteri koroner. Arteri koroner adalah arteri yang memasok oksigen dan nutrisi ke miokard. Gambaran klinis dari penyakit jantung koroner sangat bervariasi mulai dari asimptomatik sampai bergejala. ${ }^{4}$ Penyakit jantung koroner yang bersifat asimptomatik sulit untuk dilakukan screening sebagai langkah pencegahan.

Beberapa studi menunjukkan bahwa adanya hubungan kulit dan rambut (termasuk alopesia androgenik, ear lobe crease/ ELC, dan xanthoma) dengan risiko penyakit jantung koroner. ${ }^{5}$ Pada tahun 1973, ditemukan adanya ear lobe crease (ELC) bilateral maupun unilateral pada sejumlah besar pasien dengan satu atau lebih faktor risiko penyakit jantung koroner. ${ }^{6}$ Ear Lobe Crease atau Frank's sign berupa lekukan miring yang melapisi lobus telinga disebut sebagai penanda penyakit kardiovaskular. ${ }^{7}$

Deteksi penyakit kardiovaskular sebagai tindakan pencegahan dapat dilihat melalui pemeriksaan fisik. Pengukuran lingkar pinggang, Ankle Brachial Index (ABI) sangat berguna untuk penanda aterosklerosis subklinis, begitu pula dengan Ear Lobe Crease. Beberapa dekade yang lalu, beberapa studi membahas hubungan Ear Lobe Crease dengan penyakit jantung koroner. Namun sampai saat ini, pemeriksaan Ear Lobe Crease untuk menilai penyakit jantung koroner kurang mendapat perhatian petugas medis. ${ }^{8}$

Ear Lobe Crease (ELC) atau Frank's sign telah lama dikenal sebagai penanda potensial penyakit kardiovaskular. Ear Lobe Crease adalah penanda eksternal independen yang mudah diidentifikasi sebagai penanda aterosklerotik. Ear Lobe Crease berupa lekukan miring di kulit yang melapisi telinga. Juga didefinisikan sebagai garis yang menutupi kurang lebih sepertiga dari panjang antara tragus dan lobus tepi posteroinferior. $^{8}$ Dari penelitian yang dilakukan di United Kingdom, hampir semua pasien yang berisiko penyakit jantung koroner akan ditemukan ELC.

Pada tahun 1970an dikemukakan bahwa Ear Lobe Crease (ELC) dan penyakit kardiovaskular saling berhubungan. Ini disebabkan karena lobus telinga dan jantung disuplai oleh arteri terminal tanpa ada kemungkinan untuk terjadi sirkulasi kolateral. Pendapat lain mengatakan bahwa kehilangan dan degenerasi dari elastin dan sobekan serat elastin yang terlihat di spesimen biopsi dari lobus telinga pasien dengan penyakit kardiovaskular menggambarkan penyakit mikrovaskular yang ditemukan di pembuluh darah koroner. ${ }^{9-11}$

Studi lain menyebutkan bahwa ELC menggambarkan penuaan kulit karena ELC tidak ditemukan pada bayi. Selain itu, penuaan kulit berbanding lurus dengan perubahan arteri koroner. .-11 $^{-8}$

Studi di Jepang yang dilakukan pada pasien pria dengan ELC disertai faktor risiko multipel penyakit kardiovaskular didapatkan pemendekan telomer dalam sel 
darah putih yang berdampak pada proses degenerasi. ${ }^{9-11}$

\section{METODE PENELITIAN}

Penelitian ini dilakukan menggunakan metode penelitian analitik observasional dengan case control. Penelitian dilaksanakan di Irina $\mathrm{F}$ dan di Bagian Cardiovascular and Brain Center RSUP Prof Dr. R. D. Kandou Manado selama bulan Oktober sampai Desember 2015. Sampel penelitian ialah 45 pasien dengan Penyakit Jantung Koroner yang dirawat di Irina $\mathrm{F}$ dan di Bagian Cardiovascular and Brain Center RSUP Prof Dr. R. D. Kandou Manado sebagai kelompok kasus dan 45 sampel sehat sebagai kelompok kontrol.

\section{HASIL PENELITIAN}

Tabel 1. Jumlah sampel berdasarkan jenis kelamin

\begin{tabular}{lcc}
\hline Variabel & Kasus & Kontrol \\
\hline Pria, $\mathrm{n}(\%)$ & $33(73,3)$ & $18(40)$ \\
Wanita, $\mathrm{n}$ & $12(26,7)$ & $27(60)$ \\
$(\%)$ & $45(100)$ & $45(100)$ \\
\hline
\end{tabular}

Tabel 2. Frekuensi subyek penelitian berdasarkan kelompok usia

\begin{tabular}{ccc}
\hline Kelompok Usia & $\begin{array}{c}\text { Kelompok } \\
\text { kasus (n }= \\
\mathbf{4 5 )}\end{array}$ & $\begin{array}{c}\text { Kelompok } \\
\text { kontrol (n } \\
=\mathbf{4 5})\end{array}$ \\
\hline 30-39 tahun, n (\%) & $1(2,2)$ & $7(15,56)$ \\
40-49 tahun, n (\%) & $6(13,3)$ & $8(17,78)$ \\
50-59 tahun, n (\%) & $10(22,2)$ & $19(42,2)$ \\
60-69 tahun, n (\%) & $17(37,78)$ & $7(15,56)$ \\
70-79 tahun, n (\%) & $10(22,2)$ & $3(6,67)$ \\
80-89 tahun, n (\%) & $0(0)$ & $1(2,2)$ \\
90-99 tahun, n (\%) & $1(2,2)$ & $0(0)$ \\
Jumlah, n (\%) & $45(100)$ & $45(100)$ \\
\hline
\end{tabular}

Tabel 3. Hasil olahan data Hubungan ELC engan PJK

\begin{tabular}{cccc}
\hline ELC & \multicolumn{2}{c}{ PJK } & Jumlah \\
\cline { 2 - 3 } & Positif & $\begin{array}{c}\text { Negati } \\
\text { f }\end{array}$ & \\
\hline Positif & 36 & 14 & 50 \\
Negatif & 9 & 31 & 40 \\
Jumlah & 45 & 45 & 90 \\
\hline
\end{tabular}

Tabel 4. Uji X² (Chi Square)

\begin{tabular}{lccc}
\hline & Value & df & $\begin{array}{c}\text { Asymp. Sig. } \\
\text { (2-sided) }\end{array}$ \\
\hline $\begin{array}{l}\text { Pearson } \\
\text { Chi- } \\
\text { Square }\end{array}$ & $21.780^{\mathrm{a}}$ & 1 & .000 \\
\hline
\end{tabular}

Tabel 5. Odd Ratio

\begin{tabular}{lccc}
\hline \multicolumn{3}{c}{ Risk Estimate } \\
\hline & Value & \multicolumn{2}{c}{$\begin{array}{c}\text { Interval } \\
\text { Intenfidence }\end{array}$} \\
\cline { 3 - 4 } & & Lower & Upper \\
\hline $\begin{array}{l}\text { Odds Ratio for } \\
\begin{array}{l}\text { Ada tidaknya ELC } \\
\text { (Positif / Negatif) }\end{array}\end{array}$ & 8.857 & 3.373 & 23.256 \\
\hline
\end{tabular}

\section{BAHASAN}

Dari data karakteristik subyek penelitian untuk kelompok kasus yang diambil (Tabel 1) berjumlah 45 sampel terdapat 33 sampel pria (73,3\%) dan 12 sampel wanita $(26,7 \%)$. Sedangkan sampel untuk kelompok kontrol diambil sebanyak 45 orang sehat yang bersedia dilakukan penelitian. Dan dari data karakteristik subyek penelitian untuk kelompok kontrol yang diambil (Tabel 1) berjumlah 45 sampel terdapat 18 sampel pria (40\%) dan 27 sampel wanita (60\%).

Usia subyek penelitian pada kelompok kasus dan kelompok kontrol adalah tiga puluh tahun keatas. Didapatkan subyek penelitian termuda berusia 30 tahun dan yang tertua berusia 92 tahun dengan modus adalah 57 tahun.

Berdasarkan pengelompokkan usia (Tabel 2), kelompok usia terbanyak digunakan dalam pengambilan data kelompok kasus adalah kelompok usia 60 69 tahun sebanyak 17 orang $(37,78 \%)$, diikuti dengan 50 - 59 tahun dan $70-79$ tahun sebanyak masing - masing 10 orang (22,2\%), 40 - 49 tahun sebanyak 6 orang (13,3\%), serta kelompok usia 30 - 39 tahun dan 90 - 99 tahun berjumlah masing masing 1 orang (2,2\%). Sedangkan kelompok usia terbanyak digunakan dalam pengambilan data kelompok kontrol adalah kelompok usia 50 - 59 tahun sebanyak 19 orang (42,2\%), diikuti dengan $40-49$ tahun sebanyak 8 orang (17,78\%), 30 - 39 
tahun dan 60 - 69 tahun masing - masing berjumlah 7 orang (15,56\%), 70 - 79 tahun sebanyak 3 orang $(6,67 \%)$, dan $80-89$ tahun didapatkan 1 orang (2,2\%).

Berdasarkan pengambilan data (Tabel 3), didapatkan sampel dengan PJK yang memiliki ELC sejumlah 36 orang, sampel PJK tanpa ELC adalah 9 orang, sampel kontrol atau non PJK yang memiliki ELC sejumlah 14 orang, dan pasien kontrol tanpa ELC sejumlah 31 orang. Setelah itu data diolah menggunakan uji $\mathrm{X}^{2}$.

Berdasarkan uji $X^{2}$ (Tabel 4), diperoleh $X^{2}=21,78$ dengan $p<0,001$. Hasil ini menunjukkan bahwa adanya hubungan yang sangat bermakna antara Ear Lobe Crease (ELC) dengan Penyakit Jantung Koroner ( $\mathrm{p}<0,001)$. Dalam uji ini (Tabel 5), juga diperoleh OR = 8,9 $(95 \%$ CI: 3,4 - 23,3). Odd Ratio (OR) ini menyatakan bahwa bila seseorang ditemukan adanya ELC, maka orang tersebut berisiko 8,9 kali mendapat Penyakit Jantung Koroner dibanding dengan orang tanpa ELC.

\section{SIMPULAN}

Dari hasil penelitian dan bahasan dapat disimpullkan bahwa terdapat hubungan antara Ear Lobe Crease dengan Penyakit Jantung Koroner.

\section{DAFTAR PUSTAKA}

1. WHO. Cardiovascular disease. (cited 2015 Sept 13). Available from: http://www.who.int/cardiovascular_di seases/en/.

2. Kementerian Kesehatan RI. 2013. Riset Kesehatan Dasar 2013. Jakarta:
Badan Penelitian dan Pengembangan Kesehatan.

3. Syukri AE, Panda L, Rotty LW. Profil Penyakit Jantung Koroner di Irina F Jantung RSUP Prof. Dr. R. D. Kandou Manado. E-Clinic. 2013;1(1).

4. Rilantono LI. Penyakit Jantung Koroner. In: Penyakit Kardiovaskuler (PKV) 5 Rahasia. Rahajoe U, Karo-Karo S. Jakarta: FKUI, p.121.

5. Morteza AE, Meisam AE. Prevalence of Dermatologic Features in Patients with Ischemic Heart Disease. Shiraz E-Med J. 2015;16(1):e26243.

6. Frank ST. Aural Sign of Coronary-artery disease. N Engl J Med 1973;289:3278.

7. Gulsin GS, Clement KD, Anglim N. Frank's Sign as a Marker of Coronary Artery Atherosclerosis. J Cardiol Clin Res. 2014;2(3):1032.

8. Lopez CR, Diaz HG, Mariscal RM, Cervilla PJ, Graciani A, Sendon JL, et al. Earlobe Crease Shapes and Cardiovascular Events. Am J Cardiol 2015;116:286-293.

9. Scully C, Friedlander AH. Diagonal Ear Lobe Crease and Atherosclerosis: A review of the Medical Literature and Oral Maxillofacial Implications. J Oral Maxillofac Surg. 2010;68:304350.

10.Salamati P, Nazeri I, Alehossein M, Sotoudeh K, Rezaee A. Earlobe Crease and Coronary Artery Disease. Pak J Med Sci 2008;24(4):600-3.

11.Friedlander AH, Lopez JL, VelascoOrtega E. Diagonal Earlobe Crease and Atherosclerosis: A Review of the Medical Literature and Dental Implications. Med Oral Patol Oral Cir Bucal. 2012;17(1):e153-9. 